\title{
Personal features and management activities related to cattle welfare
}

\author{
Martínez-Castro, César J. *; Kido-Gruz, María Teresa; Zúñiga-Marroquín, Tania; \\ Becerril-Morales, Felipe; Ureña-Castillo, Flor D. \\ Universidad del Papaloapan, Campus Loma Bonita, Loma Bonita, Oaxaca, México, C. P. 68400. \\ * Correspondence: c_julios4@hotmail.com
}

Citation: Martínez-Castro, C. J., Kido-Cruz, M. T., Zúñiga-Marroquín, T., Becerril-Morales, F., \& UreñaCastillo, F. D. (2021). Personal features and management activities related to cattle welfare. Agro Productividad. https://doi.org/ 10.32854/agrop. v14i12.1979

Editor in Ghief: Dr. Jorge Cadena Iñiguez

Received: March 3, 2021. Accepted: November 14, 2021. Published on-line: December 20, 2021

This work is licensed under a Creative Commons Attribution-NonCommercial 4.0 International license.

\begin{abstract}
Objective: To describe the personal features, as well as the management activities related to cattle welfare in Loma Bonita, Oaxaca, Mexico.

Design/Methodology/Approach: This is a cross-sectional, descriptive, and quantitative study. The sampling was non-probabilistic for convenience. Between December 2019 and March 2020, a questionnaire was applied to 27 farmers.

Results: The average age of the ranchers is 44.6 years; $55.6 \%$ have more than 20 years of experience; $25.9 \%$ herd their cattle using a stick; $48.1 \%$ do not disinfect the udders; and $25.1 \%$ do not wash their hands during milking.

Study Limitations/Implications: The results and conclusions are limited to the sample used in the present study. Therefore, extending them to all livestock farmers in the municipality would require a broader study that considers statistical techniques of probabilistic sampling.

Findings/Conclusions: There are management activities outside the parameters established by the appropriate sanitary and welfare practices of cattle. However, the personal features indicate the existence of conditions related to the livestock activity in Mexico, that encourage participants to propose and carry out programs, plans, and strategies aimed at promoting and applying practices on animal welfare, thereby improving the productive, reproductive and profitability parameters.
\end{abstract}

Keywords: Cattle, personal features, animal welfare.

\section{INTRODUCTION}

The issue of cattle welfare acquired greater relevance, particularly in the first two decades of this century, given its association with the increase in productive and reproductive parameters, as well as economic benefits (Ramírez-Iglesia et al., 2016). Additionally, consumers are concerned and exercise pressure regarding livestock breeding or the production of food of animal origin, of which they are the final consumers. Consequently, improving the conditions and traditional management enables ranching practices which include better treatment and attention to animals (García-Castro et al., 2019).

\section{西}


Despite the above, the study of activities related to animal welfare in Mexico does not constitute yet a priority objective in agricultural and livestock development plans. In fact, researches about indicators that make it possible to measure welfare in cattle herds -in which the characteristics of each region, municipality or locality are consideredremain scarce. Another problem that has been detected within the Mexican agricultural and livestock sector is that - even if technicians, researchers, government agencies, and others make suggestions about the adoption of technologies, techniques or methods aimed at increasing the livestock productivity - these suggestions have not been adopted or incorporated into the production process, because the personal features of the producers are not taken into account (Salas-González et al., 2013).

In addition, not only does Mexico have a wide range of climates and geographic conditions, but also a cultural, social, and economic diversity that generates variations in idiosyncrasy, traditions, customs, manner, and treatment towards cattle, from one geographic space to another, or even within the same space. (Juárez-Barrientos et al., 2015). Therefore, research on animal welfare is expected to have an impact in at least three aspects: a) to contribute with producers to improve livestock management conditions that will be reflected in higher productive, reproductive and financial parameters; b) to generate public policies for a more humane and comfortable animal production; and c) to guarantee that consumers can purchase higher quality products of animal origin, produced under welfare conditions.

In the case of Loma Bonita, Oaxaca, Mexico, some effort has been made to characterize cattle production units, both in this municipality and in surrounding towns. However, there is a lack of information regarding producers and management activities related to the welfare of the cattle, even though cattle ranching is one of the main economic activities of the area. The objective of this study was to describe the personal features of the producers, as well as the management activities related to cattle welfare in production units of the municipality of Loma Bonita, Oaxaca, Mexico.

\section{MATERIALS AND METHODS}

\section{Study Area Location}

The work was carried out in cattle production units of the municipality of Loma Bonita, Oaxaca, which is located between the following geographic coordinates: $95^{\circ} 53^{\prime} \mathrm{W}$ and $18^{\circ} 06^{\prime} \mathrm{N}$; at 30 masl (INEGI, 2002). The climate is hot subhumid (Aw2(i')g), with a $>1600$ $\mathrm{mm}$ average annual precipitation, and $25^{\circ} \mathrm{C}$ annual average temperature (García, 2004), with maximum temperatures exceeding $40^{\circ} \mathrm{C}$.

This is a cross-sectional, descriptive, and quantitative research (Cortés-Cortés and Iglesias-León, 2004). The population under study were dairy cattle producers. The reporting units were the owners and/or managers of the production unit.

The sampling was non-probabilistic for convenience, with the support of the person in charge of the Regional Ranchers' Association of Loma Bonita. Twenty-seven surveys were applied from December 2019 to March 2020. The questionnaire was composed of four personal factors: age (years), gender, experience in the activity, and schooling. According to the literature (Barba et al., 2015; Pérez and Larios, 2018; Cuevas-Reyes, 2019; Flores 
-González et al., 2019), these factors can influence the adoption of technology and/or new knowledge by producers. The management activities related to cattle welfare included seven practices: 1) roundup, 2) colostrum supply, 3) navel cutting, tying, and disinfection 4) dehorning, 5) dehorning method, 6) hand washing, and 7) udder washing or cleaning. The information was registered in an Excel sheet and analyzed using descriptive statistics - such as mean, standard deviation, ranges, and percentages - to describe the producers and management activities.

\section{RESULTS AND DISGUSSION}

\section{Personal Features}

The average age of the 27 producers was 44.96 years $( \pm 13.7$ years), the oldest producers were 68 years old, and the youngest were 21 years old. Most of the producers had approximately 35 years (Figure 1). The average age below 50 years is similar to the results reported by Oros et al. (2011) and Flores-González et al. (2019).

According to the SAGARPA-FAO (2014) criteria, the average age of the cattle ranchers in the municipality of Loma Bonita, Oaxaca, is indicative of a young rural population (up to 50 years old). This situation gains traction, because young producers are considered to be more susceptible to adopt new technologies, knowledge, techniques, etc. than old producers (more than 50 years old) (García-Salazar et al., 2018; Pérez and Larios, 2018). In theory, this would facilitate the training of producers on issues related to cattle welfare, through technical assistance, in the municipality of Loma Bonita, Oaxaca.

Regarding gender, $96.3 \%$ of the participants were men and there was only one woman, which indicates that this is a male-dominated activity. Vilaboa-Arroniz et al. (2009) and Martínez et al. (2012) also report similar findings in cattle ranching from municipalities and communities of the Papaloapan region, Mexico. These results perhaps indicate that this activity involves a great deal of physical work, that management is up to a certain point carried out far from the producer's home, and that it requires investing a considerable amount of time and assuming risks, both in the herding and inside the production unit. It is also possible that the land ownership remains under a patriarchal model, in which women do not have access or control over livestock activities.

This is important because some researches (Martínez and Gómez, 2012; Barba et al., 2015) had reported that the chances of adopting a technology are greater when the person in charge of an agricultural and livestock production unit is a man, because they have

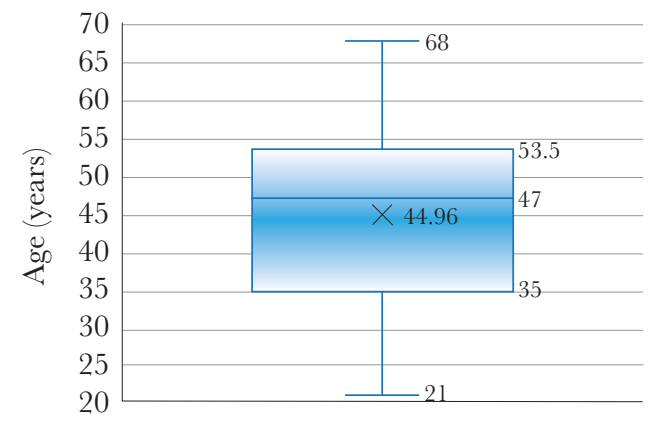

Figure 1. Age of cattle producers from Loma Bonita, Oaxaca, Mexico. 
more access and decision-making power regarding the use of technologies than women. According to the results obtained in this study, this situation would also favor the spreading and adoption of practices aimed at animal welfare.

Regarding the level of schooling, 7 (25.9\%) and 8 (29.6\%) producers had attended elementary and secondary education (55.5\% of the producers). The remaining $44.4 \%$ was distributed among those who had had attended high school (18.5\%), obtained an undergraduate or postgraduate degree (14.8\%), and those who did not have studies $(11.1 \%)$ (Figure 2). These results indicate that more than $60 \%$ of the producers have studies above elementary school, which contrasts with the findings of Chalate-Molina et al. (2010), Oros et al. (2011), and Martínez et al. (2012), for dual-purpose cattle production systems under similar agroclimatic conditions, in the states of Chiapas, Morelos, and Veracruz, respectively, where the schooling average was $\leq 6$ years. Mejía and Oliver (2005) and Flores-González et al. (2019) reported higher percentages of producers with elementary education.

There is a positive relationship between the level of schooling and the ability to adopt technology, since the adoption possibilities are greater at higher level of schooling (VargasCanales et al., 2018; Cuevas-Reyes, 2019), which would also favor the promotion of technical assistance and the training of producers on animal welfare issues.

With regard to experience, $44.4 \%$ said they had been practicing cattle ranching for less than 20 years and the remaining 55.6\% (15 producers) said they had more than 20 years of experience. Vilaboa-Arroniz et al. (2009), Oros et al. (2011), Torres et al. (2014), and other authors also report an average experience of more than 20 years. Experience in agricultural and livestock activities is also considered essential for the adoption of technologies and knowledge. Therefore, producers who have been carrying out an activity for the longest time are more likely to adopt the technology (Vargas-Canales et al., 2018). This can benefit training and technical advice programs aimed at the implementation of strategies and plans that favor cattle welfare in the municipality of Loma Bonita, Oaxaca.

\section{Animal Management and Welfare Activities}

With regard to roundup methods, $74.1 \%$ of the producers said that they whistle and speak to the animals; the remaining 25.9\% (7) mentioned that they hit them with sticks

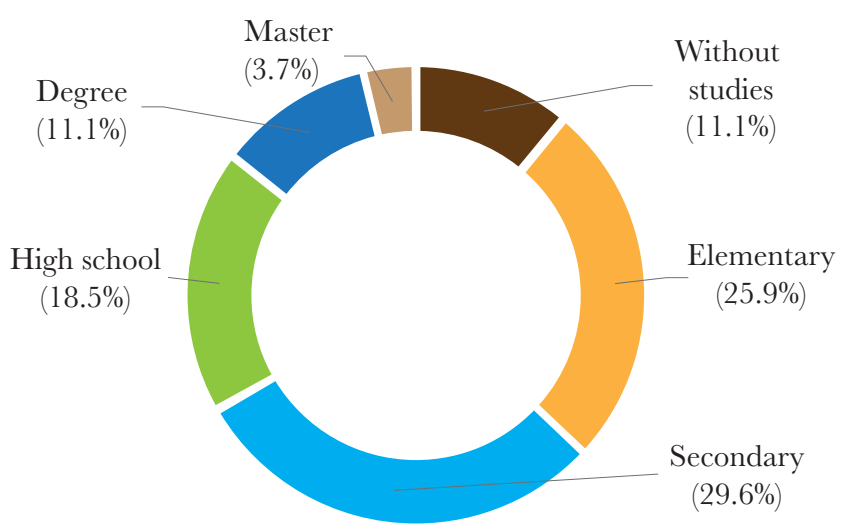

Figure 2. Level of schooling of the cattle producers of Loma Bonita, Oaxaca, Mexico. 
and yell at them before taking them to be milked (Table 1). These results show the use of the three existing types of operator-animal interactions; the highest percentage belongs to the auditory and visual interactions. In general, a calm roundup could be observed in most of the ranches; the animals were docile and obedient. These observations support the findings of Herrán et al. (2017), who found that these interactions generate few behavioral responses and calmer cattle management.

In relation to colostrum supply, all producers declared that they helped the newborn calves to suckle; this process allows them to obtain their first nutrients outside the womb and to develop antibodies to face future diseases. The results are similar to the findings of Mejía and Oliver (2005), who reported that calves in municipalities in the Colombian high tropics obtained colostrum mainly from their mothers, followed by colostrum from a colostrum bank. Natural breastfeeding and the use of a bottle are the two methods through which they are supplied colostrum. Additionally, Reyes et al. (2011) suggested washing the udder of the cow before allowing the calf to suckle, to avoid the transmission of infections to the calf, as part of the colostrum supply and cattle welfare in tropical regions. Calves should be allowed to suckle as much colostrum as they wants for the first three to four days after calving. If the calf does not suck all the colostrum, the excess should be milked to prevent engorgement and damage to the udder.

Regarding the birth of the calves, 17 producers (63\%) stated that they cut and tie the navel and apply methylene blue to prevent possible infections in newborns, while the remaining 10 (37\%) accepted that they do not apply anything. The percentage of producers who heal the navel $(67 \%)$ is lower than the $86 \%$ - regarding the healing of calves with iodine in milk-producing farms located in the high tropics of Colombia - reported by Mejía and Oliver (2005).

Twenty-one farmers (77.8\%) stated that they still dehorn their animals, while the remaining 22.2\% mentioned that they no longer do it. Out of the 21 producers who dehorn their cattle, 16 (76.2\%) use scissors or hot iron; the remaining $23.8 \%$ apply paste. In this regard, Ordoñez and Caicedo (2016) pointed out that cutting and cauterizing with hot iron is the most painful disbudding method, which represents another area of improvement for Loma Bonita producers.

Regarding the washing or disinfection of hands before milking, 6 producers $(22.2 \%)$ neither wash nor disinfect their hands; while the remaining $77.8 \%$ affirmed that they do.

Table 1. Management activities related to cattle welfare in Loma Bonita, Oaxaca, Mexico.

\begin{tabular}{l|r|r}
\multicolumn{1}{c|}{ The producer or person in charge of the production unit... } & Yes (\%) & No (\%) \\
\hline 1. Gathers the cattle hitting them when he takes them to be milked & 25.9 & 74.1 \\
\hline 2. Supplies colostrum within the first hours after calving & 100.0 & 0.0 \\
\hline 3. Ties, cuts, and disinfects the navel of newborn calves & 63.0 & 37.0 \\
\hline 4. Dehorns calves within the first three months of age & 77.8 & 22.2 \\
\hline 5. Dehorns with scissors or hot iron* & 76.2 & 23.8 \\
\hline 6. Washes his hands before milking & 77.8 & 22.2 \\
\hline 7. Washes or cleans the udder before milking & 51.9 & 48.1 \\
\hline
\end{tabular}

*Percentages calculated based on the 21 producers who dehorned with scissors or hot iron. 
Additionally, 13 producers (48.1\%) do not wash or clean the udders. These results match the findings of Calderón et al. (2009) and Mendoza et al. (2017), who warn that the lack of hygiene or and the implementation of poor practices prior to and during milking are associated with mastitis, resulting in a reduced production, increased treatment costs, and reduced milk quality. In the case of Loma Bonita, it is worth mentioning that 16 (59.3\%) out of the 27 producers reported mastitis problems in their farms, which could be associated with these bad practices.

\section{GONGLUSIONS}

Based on the personal features of the 27 cattle producers from the municipality of Loma Bonita, Oaxaca, included in the sample used for this research, we conclude that there are conditions that encourage the different actors of livestock activity in Mexico (extensionists, researchers, etc.) to propose and carry out programs, plans, and strategies aimed to promote and apply good cattle practices. These programs, plans, and strategies should be focused on providing welfare within the production units, particularly in those that have human-animal interaction, including: rounding-up without hitting the animals; cutting, tying, and disinfecting the navel of newborn calves; dehorning calves; and washing and/or disinfecting hands and udders.

\section{ACKNOWLEDGEMENTS}

The authors would like to thank PRODEP, for their support of the "Caracterización del manejo zootécnico en unidades de producción bovina de la region en términos de bienestar animal" Project. The authors would also like to thank Mr. Francisco Javier Sagastume García (veterinary-zootechnician) and the participating producers.

\section{REFERENGES}

Barba, A., Espinosa, J., Suris, M. (2015). Adopción de prácticas para el manejo agroecológico de plagas en la sandía (Citrullus lanatus Thunb.) en Azuero, Panamá. Revista de Protección Vegetal 30(2): 104-114.

Calderón, A., Martínez, N., Cardona, J. (2009). Determinación de factores de protección para mastitis bovina en fincas administradas bajo el sistema doble propósito en el municipio de Montería. Revista UDCA Actualidad y Divulgación Científica 12(2): 61-68.

Chalate-Molina, H., Gallardo-López, F., Pérez-Hernández, P., Lang-Ovalle, F.P., Ortega-Jiménez, E., Vilaboa, A.J. (2010). Características del sistema de producción de bovinos de doble propósito en el estado de Morelos, México. Zootecnia Tropical 28(3): 329-339.

Cortés-Cortés, M.E., Iglesias-León, M. (2004). Generalidades sobre metodología de la Investigación. Ciudad del Carmen: Universidad Autónoma del Carmen.

Guevas-Reyes, V. (2019). Factores que determinan la adopción del ensilaje en unidades de producción ganaderas en el trópico seco del noroeste de México. Ciencia y Tecnología Agropecuaria, Mosquera (Colombia) 20(3): 467-477.

Flores-González, A., Jiménez-Ferrer, G., Castillo-Santiago, M., Ruíz de la O, G., Covaleda, S. (2019). Buenas prácticas ganaderas: adopción de tecnologías en la Cañada Río Perlas, Ocosingo, Chiapas, México. Tropical and Subtropical Agroecosystems 22(1): 87-96.

García-Castro, F.E., Zúñiga-López, A., Flórez-Castañeda, D.C., Cubides-Cárdenas, J.A. (2019). Niveles de ruido durante el ordeño de lecherías con sistemas mecánicos del trópico alto colombiano y su efecto en la calidad de leche y el bienestar animal. Revista de Investigaciones Veterinarias del Perú 30(2): 691-698.

García, E. (2004). Modificaciones al sistema de clasificación climática de Köppen. Distrito Federal: Instituto de Geografía-Universidad Nacional Autónoma de México.

García-Salazar, J.A., Borja-Bravo, M., Rodríguez-Licea, G. (2018). Consumo de fertilizantes en el sector agrícola de México: Un estudio sobre los factores que afectan la tasa de adopción. Interciencia 43(7): 505-510. 
Herrán, L., Romero, M., Herrán, L. (2017). Interacción humano-animal y prácticas de manejo bovino en subastas colombianas. Revista de Investigaciones Veterinarias del Perú 28(3): 571-585.

INEGI.(2002).Anuario estadístico. Edición 2002. Oaxaca tomo I. Aguascalientes: Instituto Nacionalde Estadística, Geografía e Informática. http://internet.contenidos.inegi.org.mx/contenidos/productos/prod_serv/ contenidos/espanol/bvinegi/productos/historicos/1334/702825157944-1/702825157944-1_1.pdf

Juárez-Barrientos, J.M., Herman-Lara, E., Soto-Estrada, A., Ávalos-de la Cruz, D.A., Vilaboa-Arroniz, J., Díaz-Rivera, P. (2015). Tecnificación de sistemas de doble propósito para producción de leche en el distrito de desarrollo rural 008, Veracruz, México. Revista Científica 25(4): 317-323.

Martínez, G.C.J., Cotera, R.J., Abad, Z.J. (2012). Características de la producción y comercialización de leche bovina en sistema de doble propósito en Dobladero, Veracruz. Revista Mexicana de Agronegocios 30(16): 816-824. https://www.redalyc.org/pdf/141/14123097004.pdf

Martínez, R.A., Gómez, J.D. (2012). Elección de los agricultores en la adopción de tecnologías de manejo de suelos en el sistema de producción de algodón y sus cultivos de rotación en el valle cálido del Alto Magdalena. Revista Corpoica - Ciencia y Tecnología Agropecuaria 13(1): 62-70.

Mejía, G., Oliver, O.J. (2005). Descripción de 28 fincas productoras de leche localizadas en el trópico alto colombiano. Revista de la Facultad de Medicina Veterinaria y Zootecnia (52): 24-35.

Mendoza, J. A., Vera, Y. A., Peña, L. C. (2017). Prevalencia de mastitis subclínica, microorganismos asociados y factores de riesgo identificados en hatos de la provincia de Pamplona, Norte de Santander. Revista de la Facultad de Medicina Veterinaria y Zootecnia 64(2): 11-24.

Ordoñez, V.J.A., Caicedo, C.L.A. (2016). Prácticas de manejo y bienestar animal en la producción de ganado bovino de carne en Sur América. Tesis de Licenciatura. Medicina Veterinaria y Zootecnia-Facultad de Ciencias de la Salud-Universidad de Pereira.

Oros, N.V., Díaz, R.P., Vilaboa, A.J., Martínez, D.J.P., Torres. H.G. (2011). Caracterización por grupos tecnológicos de los hatos ganaderos doble propósito en el municipio de Las Choapas, Veracruz, México. Revista Científica, FCV-LUZ 21(1): 57-63.

Pérez, M.E.D., Larios, G.R.C. (2018). Adopción de tecnologías y prácticas agropecuarias en sistemas de producción en Jinotega, Nicaragua. La Calera 18(30): 48-55.

Ramírez-Iglesia, L.N., Diaz-de Ramírez, A., Aldana-González, N.E., Bendezú-Urdaneta, H.B. (2016). Indicadores directos de bienestar animal al momento de la inseminación artificial como factores de riesgo sobre la fertilidad de un rebaño lechero tropical. Revista Cientifica 26(2): 112-129. https://www. redalyc.org/articulo.oa?id=95945988008

Reyes, J.J.E., Lares, B.C.A., Martínez, A.C.O. (2011). Manejo sanitario de ganado bovino de doble propósito. Resultados de proyectos. Sinaloa: Fundación Produce Sinaloa, A. C.-SAGARPA-Gobierno del Estado de Sinaloa. https://www.fps.org.mx/portal/index.php/publicaciones/103-pecuario/1146-manejosanitario-de-ganado-bovino-de-doble-proposito

SAGARPA-FAO. (2014). Estudio sobre el envejecimiento de la población rural en México. Ciudad de México. Ciudad de México: Secretaría de Agricultura, Desarrollo Rural, Pesca y Alimentación-Organización de las Naciones Unidas para la Alimentación y la Agricultura. https://www.agricultura.gob.mx/sites/ default/files/sagarpa/document/2019/01/28/1608/01022019-2-estudio-sobre-el-envejecimiento-de-lapoblacion-rural-en-mexico.pdf

Salas-González, J.M., Leos-Rodríguez, J.A., Sagarnaga-Villegas, L.M., Zavala-Pineda, M.Y. (2013). Adopción de tecnologías por productores beneficiarios del programa de estímulos a la productividad ganadera (PROGAN) en México. Revista Mexicana de Ciencias Pecuarias 4(2): 243-254.

Torres, Y., Rivas, J., De Pablos-Heredero, C., Perea, J., Toro-Mujica, P., Angón, E., García, A. (2014). Identificación e implementación de paquetes tecnológicos en ganadería vacuna de doble propósito. Caso Manabí-Ecuador. Revista Mexicana de Ciencias Pecuarias 5(4): 393-407.

Vargas-Canales, J.M., Palacios-Rangel, M.I., Aguilar-Ávila, J., Camacho-Vera, J.H., Ocampo-Ledesma, J.G., Medina-Cuellar, S.E. (2018). Efficiency of small enterprises of protected agriculture in the adoption of innovations in Mexico. Estudios Gerenciales 34(146): 52-52.

Vilaboa-Arroniz, J., Díaz-Rivera, P., Ruiz-Rosado, O., Platas-Rosado, D.E., González-Muñoz, S., JuárezLagunes, F. (2009). Caracterización socioeconómica y tecnológica de los agroecosistemas con bovinos de doble propósito de la región del Papaloapan Veracruz, México. Tropical and Subtropical Agroecosystems 10(1): 53-62. 